\title{
LIVING AMONG WOLVES, ACTING LIKE A WOLF: \\ LUCILIUS’ ATTACKS ON LUPUS
}

What we know as Book One of the thirty books of poetry of Gaius Lucilius (148 BCE-103 $\mathrm{BCE}){ }^{1}$ the inventor of Roman verse satire, contained, or perhaps entirely consisted of, a trial of a Roman, named Lupus. ${ }^{2}$ The trial seems to have taken place in front of the gods arranged as if they were the Senate, making this episode a Concilium deorum. ${ }^{3}$ The Lupus on trial was probably Lucius Cornelius Lentulus Lupus, consul in $156 \mathrm{BCE}$, censor in 147, and maybe

${ }^{1}$ See Herbert-Brown 1999 for these dates. Scholars agree that chronologically Lucilius' Books Twenty-six to Thirty (in mixed metres) appeared before Books One to Twenty (in hexameters), but Book Thirty seems to contain only hexameters: this difficulty is insoluble. Michelfeit 1965, 128 concludes his discussion of the date of the Concilium deorum by positing that Book Thirty appeared as a single book.

${ }^{2}$ See for instance Servius on Aen. 10.104: ACCIPITE ERGO ANIMIS totus hic locus de primo Lucilii translatus est libro, ubi indicuntur dii habere concilium et agere primo de interitu Lupi cuiusdam [ducis in republica], postea sententias dicere ('THEREFORE TAKE TO HEART This entire section is transferred from the first book of Lucilius, where the gods are shown holding a council and first discussing the death of a certain Lupus, afterwards stating their verdicts'). I accept the arguments of Murgia 1970 for the excision of ducis in republica.

${ }^{3}$ Lactantius, in his introduction to Inst. 4.3.12, treats Concilium deorum as Book One's title. Recently Freudenburg 2015, 100-1 has read the Concilium as made up of speeches mimicking the pro-Hellenist Appius Claudius Pulcher and the severe Cato the Elder on opposite sides of the debate, presumably over Lupus, who might (as a senator) be thought to have been depicted in his element: see next note. 
princeps senatus in $131 .^{4}$ An analysis of what happened at the Concilium deorum is critical for the study of Roman satire because Lupus is typically regarded as Lucilius' most prominent target, one of the two who immediately come to mind when Horace and Persius consider their satirical predecessor (cf. Hor. Sat. 2.1.68; Pers. 1.114-15). ${ }^{5}$

This tradition, of Lupus as Lucilius' main and most memorable target, comes about because of the intricacies of Lucilius' multivalent procedure in attacking him. We can uncover individual associations, in the specific words of Lucilius' account of the Concilium, that combine to produce a much sharper picture of the original which lay behind our sadly fragmentary material. Such identification helps to navigate and overcome in part the problem that Lucilius' poetry has mostly been preserved as individual lines quoted by later sources, such as grammarians and the dictionary of Republican vocabulary compiled by Nonius Marcellus. The upshot will be that we can better situate Lucilius' poetry in its historical and cultural context. ${ }^{6}$ The primary aspects with which this article is concerned are philosophy and, to an even greater extent, satire's relationship with the law. The former, philosophy, is plausibly an issue in the Concilium because the first line of Lucilius' Satires, aetheris et terrae genitabile quaerere tempus ('to seek the time which generated sky and earth', 1

\footnotetext{
${ }^{4}$ Discussion of the last title at Ryan 1997, 186-7. Was L. Cornelius actually Lucilius' Lupus? P. Cornelius Lentulus Lupus was princeps senatus in 121, even though he did not serve as censor (so Ryan 1997, 188-9), but there is no reason to doubt ps.-Acro on Hor. Sat. 2.1.67, whence the information about L. Cornelius comes.

${ }^{5}$ The following analysis extends the succinct comments of Ahl 1985, 95-7, and is informed by Corbeill 1996, 57-98 on name-puns in public discourse; cf. Uría 2006, 21-3 on wordplay on names in Cicero's speeches.

${ }^{6}$ This paper is therefore a partial response to the incisive comments of Gruen 1992, 285, which discount a political motivation for Lucilius' composition of the Concilium deorum.
} 
Warmington = 1 Marx), is clearly concerned with natural philosophy. ${ }^{7}$ Meanwhile the latter issue, legality, is often recognized as a feature of the Concilium which is, obviously, a trial with Lupus as defendant. For instance, a fragment assigned to Book One mentions a lex satura, which is thought be an 'omnibus law': per saturam aedilem factum qui legibus soluat ('who may absolve through the "omnibus law" the elected aedile', 47 Warmington $=48$ Marx). ${ }^{8}$ However, one particular close connection of the Concilium, and especially its target, with an actual aspect of the law has not yet been noticed, even though the legal reality, to which I argue Lucilius alludes, is itself notorious for its archaic and memorable zeal. ${ }^{9}$

The proposals I make here rest on wordplay, which becomes an important ideological feature of Lucilius' satire, through its toying with our expectations and its relation to lived experience (as in nicknaming or name-calling). ${ }^{10}$ There are other examples of wordplay in

${ }^{7}$ See e.g. Hass 2007,76 . The line is preserved as a 'beginning of twenty-one books' by Varr. L.L. 5.17, even though it is assigned by scribes to 'Lucretius', a common error. Technical competence with regard to philosophy may be an issue here, as Waszink 1972, 135 surmises, cf. Turpin 1998, who reads the first three diatribe satires of Horace as a parody of an incompetent Epicurean philosopher (the speaker as parasite). Mayer 2005, 150-3 conveniently lays out what we know about philosophy in Lucilius.

${ }^{8}$ See e.g. Coffey 1989, 17; Gowers 1993, 113-16.

${ }^{9}$ This enquiry has affinities with the methodology of Mazurek 1997 and the response of Cairns 2005, regarding Hor. Sat. 1.9, which has been argued to be Lucilian by Ferriss-Hill 2011. See also McGinn 2001 and Lowrie 2005, especially 422 n.3.

10 Wordplay is serious business, cf. the mission statement of the first sentence of the Festschrift for Ahl: 'Wordplay is intricately enmeshed with powerplay in Latin language and poetry' (Ziogas 2016, 1). This article extends that volume's preoccupations back to an earlier generation of poetry. 
Lucilius' corpus, such as a reference to a phallic amulet, a scaevola (Varr. L.L. 7.97), which may be punning on the name of the defendant Scaevola in Lucilius Book Two, ${ }^{11}$ and the present discussion takes further the implications of the references already identified by others in the Concilium. Lucilius is always attentive to details of morphology and gender, including differences between Latin and Greek - a cultural clash usually seen as grounds for the critique of Lupus. ${ }^{12}$ This argument also assumes that intratextuality is present between two parts of Lucilius' text which mention the same character, Lupus. ${ }^{13}$

In this reading of the Concilium, the alternative animal meanings (fish and wolf) for Lupus' name are a focus for satirical mockery, in interplay with canine identity. We can then adduce an earlier passage of Lucilian poetry, which invokes Lupus' procedure as a judge in philosophical vein, and examine how philosophy seeps into the animal metaphors of the Concilium by retailing how they feature in other instances of philosophical argumentation. I suggest that Lucilius not only capitalizes on such philosophical implications, but also plays self-knowingly with the fact that his own name, with its wolfish beginning, shares one of those meanings. The present analysis reveals that Lupus' judgement on the earlier occasion

${ }^{11}$ 67-9 Warmington $=78-80$ Marx, with Marx 1905, 36-7. See also Titus as a dove or phallus in the same trial from Book Two (92-3 Warmington = 93-4 Marx, with Jones 1989), and the bloated line 568 Warmington $=541$ Marx with its multiple elisions visually representing ugliness, cf. Morgan 2010, 328, 332-3.

${ }^{12}$ For Lupus, see e.g. Freudenburg 2001, 152-3. Corbeill 2015: 53-4 has a Lucilian example, though not from the Concilium, of a deliberate and unparalleled alteration to the spelling and gender of the word $c(h) a r t a$ in line with the Greek form. Philosophy is often stigmatized as Greek, and therefore treated with some awkwardness by satirists: Mayer 2005, 146.

${ }^{13}$ This is not to impute the existence of a unifying reference between the fragments; see Sharrock 2000 for a (relatively loose) methodological framework for intratextuality. 
resembles a penalty for parricide with a wolfish component, which must be factored in to our understanding of the Book One Concilium. The result is to underscore that the literary artifice of Lucilius' satire closely interacts with an atmosphere of contemporary cultural relevance, and thus that his poetry's mockery is finely tuned already, belying its reputation from Horace as long-winded and diffuse (e.g. garrulus atque piger scribendi ferre laborem | scribendi recte: nam ut multum, nil moror, 'he was garrulous, and lazy at putting up with the work of writing, writing well—as for how much there is, I am not impressed', Hor. Sat. 1.4.12-13).

\section{COD PHILOSOPHY, DOG'S BREAKFAST, WOLF AT THE GATE}

A line preserved by Varro, in De Lingua Latina (7.47), seems to visualize Lupus overwhelmed by other dishes at a banquet: occidunt, Lupe, saperdae te et iura siluri ('O Lupus, the sauces/laws of the shabar-fish and perch are the death of you', ${ }^{14} 46$ Warmington $=$ 54 Marx). Operative here is a well-recognized play on words, alongside the conventional pun on ius: sea-bass is one meaning of the word lupus (OLD 3a). ${ }^{15}$ The other two cheap fish detract from the more expensive bass, in a $\pi \alpha \rho \grave{\alpha} \pi \rho \circ \sigma \delta$ oкí $\alpha v$ figure—one would expect the usually voracious bass to be the others' predator. ${ }^{16}$ The line is thus plausible as the concluding verdict of the Concilium, with the gods ruling on Lupus' fate. ${ }^{17}$ Nonius also

${ }^{14}$ Translations of Lucilian fragments are from Warmington 1938, with light edits. The text reproduced is that of Marx 1904, unless otherwise stated.

${ }^{15}$ Ancient sources include Varr. R.R. 3.3.9, Columel. 8.16.4, Mart. 10.30.21. Cichorius 1908, 232 concludes that fish-names were relatively common as cognomina.

${ }^{16}$ Connors 2005, 127.

17 Charpin 1978, 211-2, followed by Romano Martín 2009, 179, is surely right that this comes from near the end of the poem. This fragment is seen by all commentators as part of the Concilium, although Manuwald 2009, 53 n. 18 worries about the present tense and direct 
preserves two lines, which he says come from Lucilius Book One, that seem to have to do with a fish banquet and would therefore go well with the occidunt fragment: 'ad cenam adducam, et primum hisce abdomina tunni | aduenientibus priua dabo cephalaeaque acarnae' (50-1 Warmington $=49-50$ Marx, 'I'll bring them to dinner, and when they first turn up I shall give them tuna bellies, one each, and the heads of sea-perch'). ${ }^{18}$ But what kind of death is envisaged as the outcome of the Concilium? It could be drowning or suffocatingoxymoronically so, as a fish should be at home, by rights, in a liquid.

Of course, another meaning of the name Lupus in Latin is 'wolf' (the brunt of the entries for the lemma in $O L D$ are related to this meaning). Cornelius Lentulus consumes, like his animal counterpart (and additionally like a vulture, which he may be being called at 38 Warmington $=46$ Marx), though in his case what he consumes, in addition to the standard material luxuries which his greed demands, is the time and resources of the divine Senate, as he above all others has uniquely been chosen for the honour by Lucilius, so to speak. A confirmation of Lupus' lupine behaviour as a familiar characteristic is that a charge was levelled against him in reality: in $c .154 / 3 \mathrm{BCE}$ he had been condemned for extortion (de repetundis). ${ }^{19}$ So his wolfish name conceivably reflects his guzzling of money. ${ }^{20}$ The identification of Lupus as an animal is pertinent to another fragment from Book One of address to Lupus, who is already dead (according to Servius on Aeneid 10.104, as quoted earlier).

${ }^{18}$ See Puelma Piwonka 1949, 29 on Greek refinement here, cf. Houghton 2004, 303-4.

${ }^{19}$ Cf. Val. Max. 6.9.10, Fest. 360 Lindsay; also Liv. Per. 47.16: Broughton 1951-2, 1.451-2 n. 2. However, note Freudenburg 2015, 98-9 on an alternative date, as the Lex Calpurnia de repetundis was passed five years after the commonly held date of Lupus' trial.

${ }^{20}$ Lupus could also be recognized as a distributor of largesse, being for instance one of the backers of Terence's Heautontimorumenos: Parker 1996, 605. 
Lucilius. A fragment assigned by the grammarian Charisius, who preserves it (as does Donatus on Terence Adelphoe 282), to the book, involves a comparison of a dog's bark to the human letter $r$, 'which a dog, when it is teased, utters more plainly than a man' (irritata canes quam homo quam planius dicit, 3-4 Warmington $=2$ Marx $)$. The $r$ sound in the word irritata makes the sound performative and growl-like. But is it Lucilius who is being assimilated to a dog, set against Lupus' wolf? ${ }^{21}$ If the dog is being teased then it is not Lucilius but Lupus himself who is the target, with Lucilius perhaps the homo in the comparison. ${ }^{22}$ The fragment has been preserved because canes here is an unusual, feminine form. It seems that the god Apollo may have taken exception in Lucilius to being called pulcher because it implied effeminacy, and this may have happened in the Concilium $;{ }^{23}$ maybe Lupus is made fun of for similar reasons. $^{24}$

${ }^{21}$ As Ahl 1985, 96 has it: 'The Lucilian dog, like Horace's Molossian in Epodes 6.1-10, dined out on the senatorial wolf'. Cf. Martyn 1966, 494-5 on the relatively few images involving dogs in Lucilius.

${ }^{22}$ Romano Martín 2009, 160 thinks, on the basis that Lupus is dead by the time of writing, that it must refer not to Lucilius' art, but to the conditions which led to Lupus appearing at the Concilium.

${ }^{23}$ Servius on Verg. Aen. 3.119: pulchros enim a ueteribus exsoletos dictos; nam et apud Lucilium Apollo pulcher dici non uult ('for [they say] that "beautiful" was a term applied by old writers to debauched young men; for example, even in Lucilius Apollo does not wish to be called "beautiful"'); cf. Marx 1905, 12-13. See Waszink 1970, 271 with references back to Marx and Leo, on the possibility that Apollo is invoked in the Concilium as a 'wolf-killer' ${ }^{24}$ The fragment (33 Warmington $=46$ Marx) which mentions cinaedi ('Gigolos' in the translation of Krenkel 1970, 1.115) seems to imply effeminacy (cf. e.g. Ferriss-Hill 2015, 219). 
However, still more about the Concilium can be explained with recourse to a passage which establishes that Lupus' judicial career was previously familiar to Lucilius, and therefore to those who knew his poetry. Lupus' conduct had already been the subject of comment in Book Twenty-eight. ${ }^{25}$ The fragment seems to depict the target of the Concilium as a hanging judge, quick to convict (805-11 Warmington $=784-90$ Marx $)^{26}$

hoc cum feceris,

cum ceteris reus una tradetur Lupo.

non aderit: $\dot{\alpha} \rho \chi \alpha \tilde{\iota} \varsigma$ hominem et stoechiis simul

priuabit, igni cum et aqua interdixerit.

duo habet stoechia. ${ }^{27}$ adfuerit: anima et corpore

( $\gamma \tilde{\eta}$ corpus, anima est $\pi v \varepsilon \tilde{v} \mu \alpha)$, posterioribus

stoechiis, si id maluerit, priuabit tamen.

When you have done this, he will be handed over together with the others as a defendant to Lupus. Let's say he doesn't turn up in court: he will deprive the man of 'first beginnings' and 'elements' together, when he has forbidden him 'fire' and 'water'. He

${ }^{25}$ This fragment is preserved by [Probus] on Verg. Ecl. 6.31 as being 'Lucilius in XXVIII satyrarum'. It is dismissed in one sentence by Manuwald 2009, 52; Ahl's comments (1985, 96-7) focus on Lucilius' Concilium as a precursor for Ovid's.

${ }^{26}$ Hass 2007, 165-6 takes seriously the arrangement and summary of Krenkel 1970, 1.91-2 in judging this a comic situation to do with 'grotesken Frauenraub' (166) in the aftermath of a break-and-enter offence. That motivation is not essential to my argument about Lupus, who can at least be seen to be notorious.

${ }^{27}$ I punctuate following Shackleton Bailey 1980-1. 
has two elements left. Let's say he appears in court: of his soul and body ('earth' is body, soul is 'air'), these last two elements, if he prefers, he will deprive him nevertheless.

This passage claims to exemplify Lupus' method as a member of the judiciary, and therefore lays the groundwork for the conceit in Book One whereby the judge will be judged. In the Book Twenty-eight scenario, if the defendant does not appear (that is, has gone into exile), the judge will deprive him of two of the four elements, fire and water, by banishing him retrospectively; if he does appear, the judge will have him put to death, thus depriving him of soul and body. Notice the element of the defendant's absence in non aderit, which does not halt Lupus from carrying on regardless. ${ }^{28}$ Now take seriously Lupus' other identity as a wolf: he could be a living representation of the concept of lupus in fabula ${ }^{29}$ According to this proverb, the 'wolf in the story' is the topic of conversation who magically appears when talked about. So, by just mentioning the name Lupus, it would be impossible for him to be absent (non aderit). Indeed, it is not entirely clear from the phrasing that it is the defendant, rather than the judge, who is absent and then present in this situation-Lupus could be ruling even while otherwise occupied with multitasking.

\section{THE PHILOSOPHER AND THE WOLF}

A well-known citation of lupus in fabula is the simile in Plato's Republic 336d5, applied to the overbearing Thrasymachus as just such a wolf, almost as an incarnation of the political strongman whose rule he favours. Philosophy is part of the context of the Book Twenty-eight

${ }^{28}$ Cf. perhaps the famous and even proverbial adage of Plaut. Asin. 495: lupus est homo homini, non homo, quom qualis sit non novit, 'man is no man, but a wolf, when he has not recognized what kind of man it is'.

${ }^{29}$ Bettini 2011, 15-26. 
passage too, in the mention of the four elements. Regardless of the prospect that the trope is being comically misappropriated, Lucilius might be calling up the memory of Empedocles, who systematized just such a theory of the world's composition (DK 31 B17). ${ }^{30}$ If it is Empedocles we were meant to think of here, the sentence of exile gains additional significance: it seems that he inveighed against the leading citizens of his town Acragas and forced them into exile themselves (Plut. Mor. 1126c). Also, his persona, at one point divine, apparently went into exile as the result of a crime (DK 31 B115.13-14). Lupus the lawgiver is presented here as something of an experimental philosopher-figure, a little like Empedocles. ${ }^{31}$ Part of the joke in the Book Twenty-eight passage is that by depriving the defendant of just two of those elements he already condemns him to death: he cannot exist. These are not $\alpha \rho \chi \alpha i$; they are $\tau \dot{\varepsilon} \lambda \eta$ ('ends', potentially moral ones). ${ }^{32}$

${ }^{30}$ Preserved by Simplicius Phys. 157-58; cf. Diog. Oen. fr. 6.1.10-6.2.9 Smith, Cic. Luc. 118. Garani 2007, 228 n. 61 cites this Lucilian fragment to point out Lucretius' use of Empedocles' elements as 'unified imagery' for atomic combinations at 1.820. However, Farrell 2014, paras. 7-9 rightly points out that the theory had been assimilated by many philosophical schools after Empedocles, so Lucilius may not have expected his readers specifically to recognize that philosopher in Lupus.

31 It has been observed about Lucretius (e.g. Furley 1970; Sedley 1998, 1-34), Ennius (Bignone 1929, with some backing from Skutsch 1985, 394-95, 402) and Augustans (e.g. Hardie 1995) that Empedocles might have been important for beginning works of poetry. We might then expect Empedoclean echoes in Lucilius' Concilium, itself parodying Ennius' concilia deorum (or concilium: Timpanaro 1994, 203-25), in tandem with the four-element fragment here.

${ }^{32}$ Baier 2001, 43 has more on the interplay of law and philosophy in this passage. 
It is tempting to surmise that philosophy is relevant to the Concilium as well as the Book Twenty-eight passage, with the animal metaphors identified earlier playing a role in the allusion. Both species, dogs and wolves, have good philosophical pedigree, ${ }^{33} \mathrm{dogs}$ standing in for the Cynic philosopher, ${ }^{34}$ whereas wolves are well known as the figure for the tyrant in Plato's Republic. And Republic 8, 565d-566a, which culminates with the tyrant compared to

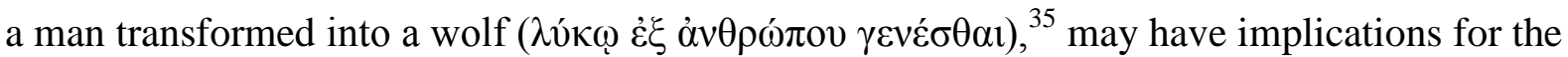
charges against Lupus in Lucilius Book One. Lupus, with his wolfish name and therefore nature, could stand accused of attempted tyranny. ${ }^{36}$ Moreover, there is a philosophical trend

${ }^{33}$ Although perhaps this is an iambic as much as a philosophical tendency, cf. Davis 1987,71 n. 13; Watson 2003, 263-4 on the introduction of the bull in Horace's Epode 6: the earlier iambists' targets were $B u$-palus and $L y c$-ambes.

34 See e.g. Puelma Piwonka 1949, 98: 'offenbar wird hier auf die kynisch-stoischen

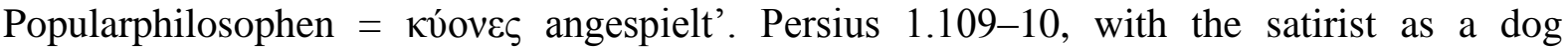
(indebted to Lucilius, 389 Warmington $=377$ Marx, and thence probably to 3-4 Warmington = 2 Marx), has a Cynic tinge: Bellandi 1996, 60. Branham 2007, 73 notes that the Cynic Diogenes' philosophy was a response to exile. Cf. Houghton 2004 on the interplay of wolves and dogs in Hor. Sat. 2.2; likewise, Watson 1983 on the iambist as sheepdog (not huntingdog) fending off wolves in Hor. Ep. 6. On the watch-dogs of Plato's Laws, see Pender 2000, $142-4$.

${ }^{35}$ On the complex of imagery here, see Petraki 2011, 245-6; see the discussion at 189-92 of

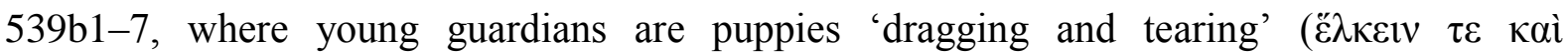
$\sigma \pi \alpha \rho \alpha ́ \tau \tau \varepsilon ı v)$ : a burlesque version of Plato's characterisation of the ideal city's guardians as watch-dogs.

${ }^{36}$ While there is no clear evidence of this charge in the fragments of Lucilius - with the only insults, as enumerated by Gruen 1992, 284, merely demonstrating animosity towards him- 
that muses on the exact differences of dogs from wolves, as Cicero makes Lucullus do, when he uses the pair as an example in discussing the difference between true and false sensations, following Antiochus in explaining away the New Academy's sorites argumentative technique: et si lupi canibus similes, eosdem dices ad extremum ('and if wolves are similar to dogs, you'll end up saying that they're identical', Luc. 50). Likewise, we can consider a nearidentical statement which Cicero gave to Cotta, another Academic Sceptic, responding critically to Velleius, an Epicurean, who has argued for the human-like rationality of gods according to the doctrine of signs, in De Natura Deorum: ${ }^{37}$

ipsa uero quam nihil ad rem pertinet, quae uos delectat maxime, similitudo. quid, canis nonne similis lupo (atque, ut Ennius, 'simia quam similis turpissuma bestia nobis'); at mores in utroque dispares. (N.D. 1.35.97)

Then take your favourite argument from resemblance: how utterly pointless it really is! Why, does not a dog resemble a wolf? — and, to quote Ennius, 'How like us is that ugly brute, the ape!'- but the two differ in habits.

Ovid twice makes his Jupiter in the speech to his Concilium deorum call Lycaon, a wolf like Lupus, a 'tyrant' (Met. 1.218,1.276). Manuwald 2011, 223 notes that Accius, Lucilius' contemporary, often features tyrants in his plays, in 'a reaction to the political situation in the late second and early first centuries BCE, which saw an increase in powerful individuals'; the accusation was levelled at Scipio Aemilianus, cf. e.g. Plut. Apophth. Scip. Min. 23 (= Mor. 201).

${ }^{37}$ See Dyck 2003, 181. Ennius' false-etymological pun in similis and simia has received the most attention in the criticism of this passage. 
Differentiating dogs from wolves, as a comparandum for trying to differentiate humans from gods, is germane to the context of the entire Concilium, where gods are portrayed in human(Senate-)like ways in judgement over a human. Thus the issue-arising from the fragment about the irritated female dog, growling onomatopoeically - of whether Lupus, with his love of consumption, ${ }^{38}$ was similar to a dog as well as his namesake wolf can be seen to have extra force, if philosophical examples are brought to bear.

But Lupus is not the only wolf in the picture. In the knowledge that emphasis on onomastic puns was a typical part of philosophical argumentative strategies, ${ }^{39}$ it is important to mention that the author of the scene, Lucilius, sports a name that begins with the syllable luk-, which makes him also a wolf, $\lambda$ v́кos. ${ }^{40}$ Lucilius elsewhere in his corpus refers in the first person to becoming a 'shape-shifter' (uersipellis fio, 653 Warmington $=670$ Marx), in a fragment universally regarded as self-referential; the word uersipellis can mean 'lycanthrope'. ${ }^{41}$ Of the three lup- words in the Lucilian fragments, ${ }^{42}$ two $(250$ Warmington $=$

${ }^{38}$ Cf. Sen. Epist. 19.10, though with a different animal, quoting Epicurus against the Stoics: 'for a dinner of meats without a friend is like the life of a lion or wolf'.

${ }^{39}$ Cf. e.g. Gale 2001, 168-9; Levin 2001, 70-5 on Heraclitus with reference to Plato's Cratylus, for etymologies in which see Barney 2001, 49-80; Heath 2011, 121-3. On names as part of iambic strategies more generally, see Ingleheart 2014.

40 The only acknowledgement of this which I have seen in print is in Geymonat 1981, speculating on Verg. Ecl. 7.52. Oddly, it is missing from the comprehensive treatment of Ahl

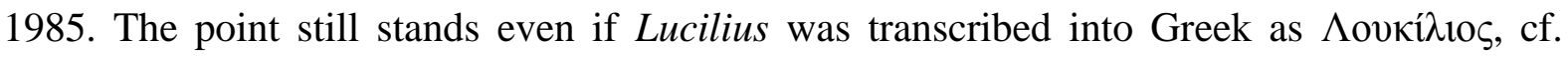
Appian B.C. 4.129, since orthography was not necessarily standardized.

${ }^{41}$ The meaning is most prominent in imperial texts (famously at Petr. 62.13), though it was used by Plautine characters to denote the clever plotting of a servus callidus (Bacch. 657) or Jupiter disguised as Amphitruo (Amph. 123). Plin. N.H. 8.80 uses the term, retailing stories 
207 Marx, 359 Warmington = 334 Marx) refer to prostitutes; the third, uetulum lupum ('that old wolf', 952 Warmington $=826$ Marx), refers to an enemy of Rome, Hannibal (named in the next line). Perhaps Hannibal is comparable to a satirist who has referred to himself as improbus ille Lucilius ('that wicked Lucilius', 929-30 Warmington $=821-2$ Marx). ${ }^{43}$ Certainly, it is well known that Lucilius is an 'old man' for Horace in Satires 2 (senis, Hor. Sat. 2.1.34). The same line of Horace's Satires 2 may also contain an oblique version of the wolf idea, through the later poet's self-presentation as a 'Lucanian or Apulian' follower of Lucilius: sequor hunc, Lucanus an Apulus anceps ('I follow this man, whether as a Lucanian or Apulian', 2.1.34) carries the tell-tale $L u c$ - as the sign. ${ }^{44}$ One consequence of any possible identity, though, is that Lucilius could be signposting his own abjection - there but for the

which seem to be derived from Varro (Veenstra 2002, 142), and referring to Euanthes (perhaps a scribal mistake for the better-attested fourth-century historian Neanthes: Bremmer 2007, 69), which pushes the date back to one where the term might have implied lycanthropy to Lucilius.

${ }^{42}$ These three are briefly treated by Martyn 1966, 497-with an allusion to Erwin Rommel as 'Desert Fox'.

43 'Soldatenjargon', says Krenkel 1970, 2.485 (like Martyn in the previous note) on the Hannibal fragment, though his reference to Hor. Epist. 2.2 .28 could work in my favour, as there may be a further pun on Luc-ullus, whose soldier is that anecdote's subject: see above for Lucullus in Cicero.

${ }^{44}$ Freudenburg 2010, 276 notes wolfishness in this connection alone. We should perhaps remember that the Hirpinian Samnites, who lived near Lucilius' birthplace, Suessa Aurunca, were led by an eponymous wolf (hirpus in the Samnite language), cf. Strabo 5.4.12: Ferrando 2003; Farney 2007, 206. 
grace of god-for comic effect. ${ }^{45}$ Another problematic implication stems from the fact that the word for wolf is Latin for Lupus but Greek for $\Lambda$ v́к-ilius: the identity of the satirist himself complicates the easy assumption that Greek influence, reflected in Lupus' moral lassitude, corrupts the target, but his attacker remains ethically pure. ${ }^{46}$ The satirist, purveyor of the one true Roman genre, in Quintilian's famous phrase (satura quidem tota nostra est, 'satire is at least totally ours', Inst. 10.1.93), is vulnerable to the charge that he is a 'wolf in sheep's clothing', so to speak, a hidden and subversive alien whose true character must be divined from his name. ${ }^{47}$

\section{SAD SACKS}

A complementary, even if still speculative, approach can take us further still by adding an allusion, regarding the law, to the couching in philosophy of the mockery of Lupus. The allor-nothing nature of the Book Twenty-eight fragment is reminiscent of the infamous poena cullei ('punishment of the sack'). This possibility goes unmentioned in the commentaries of

\footnotetext{
${ }^{45}$ A similar strategy is employed by Juvenal, e.g. in Sat. 9, where through Naevolus the poet "toys with the very notion of "mocker" and "target", and ultimately endorses the very stance of comic abjection that he simultaneously complains of and hopes to transcend' (Rosen 2007, 217).

${ }^{46}$ See e.g. Connors 2005, 128-9.

${ }^{47}$ Mayer 2005, 149 formulates the thought in relation to satiric attitudes to philosophy. Exile itself — the voluntary disappearance of the accused in the Book Twenty-eight fragment—was called a uniquely Roman punishment: Polyb. 6.14.6-8, Cic. Caec. 100.
} 
Marx and Krenkel, who instead cite Digest 48.6.11. ${ }^{48}$ In the telling of the author of the Rhetorica ad Herennium, this punishment was applied to an individual named Malleolus:

Malleolus iudicatus est matrem necasse. ei damnato statim folliculo lupino os obuolutum est et soleae ligneae in pedibus inductee sunt: in carcerem ductus est. (ad Her. 1.13.23)

Malleolus was convicted of matricide. Immediately after he had received sentence, his head was wrapped in a bag of wolf's hide, the 'wooden shoes' were put upon his feet, and he was led away to prison.

The detail that catches the eye is the wolf-skin bag, which serves to remove the convict from one of the four elements, the air. ${ }^{49}$ That interpretation, of the guilty party's segregation from nature, at least, is clear from the refinement of the punishment in Cicero's description of it in Pro Roscio Amerino:

insui uoluerunt in culleum uiuos atque ita in flumen deici. o singularem sapientiam, iudices! nonne uidentur hunc hominem ex rerum natura sustulisse et eripuisse cui repente

${ }^{48}$ Marx 1905, 276; Krenkel 1970, 2.443. The law there is cited owing to, again, a focus on house-plunder, based on their reading of the sequence of fragments.

${ }^{49}$ Cantarella 1991, 277-9 has (based on the approaches of Gernet and Nardi) a symbolic rationale for the wolf-skin, whereby the criminal is transformed into an outlaw; her account proceeds with reference to, among others, Lycaon, whose story as it appears in Ov. Met. 1 is deemed to be indebted to Lucilius' Concilium by e.g. Ahl 1985, 98-9 and Innocenti Pierini 1987. 
caelum, solem, aquam terramque ademerint ut, qui eum necasset unde ipse natus esset, careret eis rebus omnibus ex quibus omnia nata esse dicuntur? (Ros. Am. 70-1)

They therefore stipulated that parricides should be sewn up in a sack while still alive and thrown into a river. What remarkable wisdom they showed, gentlemen! Do they not seem to have cut the parricide off and separated him from the whole realm of nature, depriving him at a stroke of sky, sun, water and earth — and thus ensuring that he who had killed the man who gave him life should himself be denied the elements from which, it is said, all life derives?

The totality of this penalty for parricide in relation to the four elements matches the stringency of Lupus in Lucilius Book Twenty-eight. And death by drowning while unable to escape, let alone swim, harks back to that fragment, 46 Warmington $=54$ Marx, which mooted the submerging of Lupus, with which I began. Indeed, a fragment attributed by Nonius to Book Twenty-six, ego si, qui sum et quo folliculo nunc sum indutus, non queo ('If, being what I am and in the bag in which I am clothed, I cannot for my part', 691 Warmington = 622 Marx), could be relevant to my contentions about the satirist's knowledge of and allusion to the poena cullei. ${ }^{50}$

The poena cullei also coincides chronologically with Lucilius' floruit. Even if the Periochae of Livy seem to indicate that the Malleolus episode was treated in that author's Book 68, occurred in 101 BCE (after Lucilius' death in 103), and was a first time for the sack

${ }^{50}$ While this fragment is usually seen as part of a recusatio, on the model of Hor. Sat. 2.1see e.g. Christes 1971, 76 - the first-person context and admission of weakness dovetail with the punishment meted out by Lupus and the identity of the satirist with the target in the Concilium. 
punishment - which culminated as expected in Malleolus being thrown into the sea in the sack - to be utilized in Rome (Per. 68.9), this late date for the 'first time' of the Periochae is explicable if Malleolus was the first criminal to be treated to this punishment for matricide specifically, as opposed to patricide. ${ }^{51}$ Indeed, the dating for Malleolus in the Periochae may be untrustworthy (with Livy referring there to an earlier event), ${ }^{52}$ as at least one reference in Plautus seems to indicate knowledge of such a punishment. ${ }^{53}$ While neither in the Pro Roscio account nor in Cicero's others (Inv. 2.50.149; ad Q. Fr. 2 SB [1.2] 5.5) does a wolf-skin bag specifically feature, there is no reason to doubt the Auctor ad Herennium, and Cicero's accuracy with regard to this punishment may have doubt cast on it because of his explanation for the clogs, which he claims prevent the guilty party from running away: they can be more persuasively explained as aiming 'to avoid pollution by preventing contact with the earth' ${ }^{54}$ It is therefore likely that Lucilius' Lupus in Book Twenty-eight has something to do with the poena cullei, and then additionally plausible to ascribe the punishment some relevance to the situation, for Lucilius' audience of the earlier books to recognize, when the same extremist judge is taken to court in the Book One Concilium.

${ }^{51}$ Cantarella 1991, 274.

${ }^{52}$ For mistakes in the Periochae, see e.g. Hoyos 1998, 59, with further references.

${ }^{53}$ The opaque joke in Plaut. Epid. 349-51 is key evidence that it was current earlier than 101 BCE: quia ego tuom patrem faciam parenticidam .... peratum ductarent: ego follitum ductitabo ('because I'll turn your father into a parenticide .... People would carry a parricide off in a bag, but I shall carry your father off in a wallet'). A late third-century date is deemed by Bauman 1996, 170 'almost certainly correct' for the first sack punishment; Kyle 1998, 230 has further bibliography.

${ }^{54}$ Robinson 2007, 45, cf. Cantarella 1991, 279-80. 
If the charge of parricide which occasions the poena cullei can be delineated as the killing of a parent, ${ }^{55}$ it is especially relevant to Lucilius' Concilium in a quasi-Freudian vein. ${ }^{56}$ A fragment, preserved by Lactantius from whom the title Concilium deorum came (Inst. 4.3.12) and assigned by all editors to Lucilius Book One, muses on the title of 'father':

ut

nemo sit nostrum quin aut pater optimus diuum aut Neptunus pater, Liber Saturnus pater, Mars Ianus Quirinus pater siet ac dicatur ad unum. (24-7 Warmington = 19-22 Marx)

so that there is not one of us who is not called 'father'; 'father' the best of the gods is called; Neptune also is 'father', Liber and Saturn are 'father', Mars, Janus, Quirinus are 'father'; one and all are called so.

Lactantius claims that Lucilius inridet ('laughs at') this practice. Senators of course were called patres conscripti. But, at some point in the tradition, the term pater came to characterize not just senators but also Ennius the poet. ${ }^{57}$ If this was a Lucilian joke- or even

${ }^{55}$ But see Festus p. 221L, and Plutarch, Life of Romulus 22.4, on parricide as any kind of murder of a free man — an edict attributed to Romulus, who is fittingly both son of Quirinus and subject of Ennius' council early in the Annales. Scholarly discussion on the status quaestionis before the first century is inconclusive.

56 The identification of Freudianism is here being used loosely; cf. Oliensis 2009, 57-60 and passim.

${ }^{57}$ For pater as an especially Ennian word (18 occurrences in Skutsch's Annales index), see Prinzen 1998, 106-8, cf. Hor. Epist. 1.19.7-8, Prop. 3.3.6. For its use by Ennius as part of a 
coinage - then it is not far-fetched to see an aspect of parricide in Lucilius' divine council, as part of its likely parody of Ennius' Annales. ${ }^{58}$

\section{CONCLUSION}

Both the wolf identity, founded on the similarities in nomenclature of the target and the satirist (one Roman, one Greek-but which is which?), and the revelation that the satirist could be castigated as a parricide, are in fact a form of generic self-lowering which creates an arena for satiric critique to exist. ${ }^{59}$ The relationships and correspondences uncovered here demonstrate that in the Concilium Lucilius was being careful not to be entirely negative,${ }^{60}$ in that the compromised position of the satirist makes us think twice about the authority of his critique. To entertain a dangerous thought about authorial intentionality, one of the reasons Lupus may have been chosen as the victim of Lucilius' satire, above all other prominent and

Romanization of a Homeric inheritance, see e.g. Elliott 2013, 266 (quoting an observation of Fantham).

${ }^{58}$ See Elliott 2013, 48 n. 97 for a brisk summary of this common assumption, founded in part on the mention of a 'former council' (prius) in 20-2 Warmington = 27-9 Marx (or an 'old' one, concilio antiquo, 23 Warmington = 30 Marx), cf. Manuwald 2009, 51-2.

${ }^{59}$ Perhaps analogous is the idea that Horace punned on his own name Flaccus ('flaccid'), cf. Fitzgerald 1988, although the cautions of Parker 2000 are important; his translation of the cognomen as 'lop-eared' does not obviate the point that Horace's two mentions of his name Flaccus, one in recollection of Catullus (Epod. 15.12), and the other alongside the name Caesar (Sat. 2.1.17), emphasize its triviality in relation to others.

60 This conclusion resembles that of Manuwald 2009, 54: 'Damit besteht die Götterversammlung nicht nur aus destruktiver Kritik, sondern deutet auch Möglichkeiten einer Lösung an’. 
indeed corrupt figures, is that very resemblance of their shared name. If this reading has minimized some of the overt political significance of the Concilium itself, ${ }^{61}$ the dividend is that a fuller picture has been obtained of its cultural standing and putative relationship with other Lucilian loci. That is not at all to say that Lucilius' work is a-political: for the wordplay Lucilius employs creates an appearance of triviality with its piquant humour-the better to disarm unsuspecting and censorious readers. Acknowledgement, then, of the particular contextual elements in the portrayal of Lupus that were worthy of satirizing, as well as the tropes in which that satire took place, extends our understanding of Lucilian technique in the Concilium deorum, so we see that it was applied as a precision tool rather than broad and scattergun invective. The politically resonant historical and cultural underpinnings for Lucilius' invention of satire explain the hold which his Book One scenario had and still has over the imagination. ${ }^{62}$

\footnotetext{
${ }^{61}$ Thus the present study can be usefully read in parallel with e.g. Freudenburg $2015,98-101$. ${ }^{62}$ With thanks to the anonymous reviewer, and to many, especially Matthew Fox, Kirk Freudenburg, and Gesine Manuwald, who have made suggestions but are not responsible for infelicities in the resulting argument.
} 


\section{LITERATURE CITED}

Ahl, F. M. 1985. Metaformations. Soundplay and Wordplay in Ovid and Other Classical Poets. Ithaca, NY.

Baier, T. 2001. Lucilius und die griechischen Wörter. In Der Satiriker Lucilius und seine Zeit, ed. G. Manuwald. 37-50. Munich.

Barney, R. 2001. Names and Nature in Plato's Cratylus. London \& New York.

Bauman, R. A. 1996. Crime and Punishment in Ancient Rome. London \& New York.

Bellandi, F. 1996. Persio: dai 'verba togae’ al solipsismo stilistico (studi sui Choliambi e la poetica di Aulo Persio Flacco. Bologna.

Bettini, M. 2011. The Ears of Hermes: Communication, Images, and Identity in the Classical World, tr. W. M. Short. Columbus, OH.

Bignone, E. 1929. Ennio ed Empedocle. RFIC 7: 10-30.

Branham, R. B. 2007. Exile on Main Street: Citizen Diogenes. In Writing Exile: The Discourse of Displacement in Greco-Roman Antiquity and Beyond, ed. J. F. Gaertner. 7185. Leiden.

Bremmer, J. N. 2009. Myth and Ritual in Greek Human Sacrifice: Lykaon, Polyxena, and the Case of the Rhodian Criminal. In The Strange World of Human Sacrifice, ed. J. N. Bremmer. 55-79. Leuven.

Broughton, T. R. S. 1951-2. The Magistrates of the Roman Republic. 2 vols. New York.

Cairns, F. 2005. Antestari and Horace, Satires 1,9. Latomus 64: 49-55.

Cantarella, E. 1991. I supplizi capitali in Grecia e a Roma. Milan.

Charpin, F. 1978. Lucilius: Satires Tome I (Livres I-VIII). Paris.

Christes, J. 1971. Der frühe Lucilius. Rekonstruktion und Interpretation des XXVI. Buches sowie von Teilen des XXX. Buches. Heidelberg.

Cichorius, C. 1908. Untersuchungen zu Lucilius. Berlin. 
Coffey, M. 1989. Roman Satire. $2^{\text {nd }}$ Ed. London.

Connors, C. 2005. Epic Allusion in Roman Satire. In The Cambridge Companion to Roman Satire, ed. K. Freudenburg. 123-45. Cambridge.

Corbeill, A. 1996. Controlling Laughter: Political Humor in the Late Roman Republic. Princeton.

Corbeill, A. 2015. Sexing the World: Grammatical Gender and Biological Sex in Ancient Rome. Princeton.

Davis, G. 1987. Carmina/Iambi: The Literary-Generic Dimension of Horace's Integer vitae (C.1, 22). QUCC 27: 67-78.

Dyck, A. R. 2003. Cicero: De Natura Deorum I. Cambridge.

Elliott, J. 2013. Ennius and the Architecture of the Annales. Cambridge.

Farney, G. D. 2007. Ethnic Identity and Aristocratic Competition in Republican Rome. Cambridge.

Farrell, J. 2014. Looking for Empedocles in Latin Poetry: A Skeptical Approach. Dictynna 11: http://dictynna.revues.org/1063,

Ferrando, S. 2003. Sulle tracce del 'lupo sannita' con Strabone. Maia 55. 511-17.

Ferriss-Hill, J. L. 2011. A Stroll with Lucilius: Horace, Satires 1.9 Reconsidered. AJP 132: $429-55$.

Ferriss-Hill, J. L. 2015. Roman Satire and the Old Comic Tradition. Cambridge.

Fitzgerald, W. 1988. Power and Impotence in Horace's Epodes. Ramus 17: 176-91.

Freudenburg, K. 2001. Satires of Rome: Threatening Poses from Lucilius to Juvenal. Cambridge.

Freudenburg, K. 2010. Horatius Anceps: Persona and Self-Revelation in Satire and Song. In A Companion to Horace, ed. G. Davis. 271-90. Malden, MA. 
Freudenburg, K. 2015. Seneca's Apocolocyntosis: Censors in the Afterworld. In The Cambridge Companion to Seneca, ed. S. Bartsch and A. Schiesaro. 93-105. Cambridge.

Furley, D. 1970. Variations on Themes from Empedocles in Lucretius' Proem. BICS 17: 5564.

Gale, M. 2001. Etymological Wordplay and Poetic Succession in Lucretius. CP 96: 168-72.

Garani, M. 2007. Empedocles Redivivus. Poetry and Analogy in Lucretius. New York.

Geymonat, M. 1981. Tirsi critico di Lucilio nella settima egloga virgiliana. Orpheus n.s. 2: $366-70$.

Gowers, E. 1993. The Loaded Table: Representations of Food in Roman Literature. Oxford.

Gruen, E. 1992. Culture and National Identity in Republican Rome. Ithaca, NY.

Hardie, P. 1995. The Speech of Pythagoras in Ovid Metamorphoses 15: Empedoclean Epos. $C Q 45: 204-14$.

Hass, K. 2007. Lucilius und der Beginn der Persönlichkeitsdichtung in Rom. Stuttgart.

Heath, M. 2011. Ancient Philosophical Poetics. Cambridge.

Herbert-Brown, G. 1999. Jerome's Dates for Gaius Lucilius, Satyrarum scriptor. CQ 49: $535-43$.

Houghton, L. B. T. 2004. The Wolf and the Dog (Horace, Sermones 2.2.64). CQ 54: 300-4.

Hoyos, B. D. 1998. Unplanned Wars: The Origins of the First and Second Punic Wars. Berlin \& Boston.

Ingleheart, J. 2014. Play on the Proper Names of Individuals in the Catullan Corpus: Wordplay, the Iambic Tradition, and the Late Republican Culture of Public Abuse. JRS 104: 51-72.

Innocenti Pierini, R. degl'. 1987. Il concilio degli dèi tra Lucilio e Ovidio. A\&R 32: 137-47.

Jones, F. M. A. (1989), A Note on Lucilius 88-94 M. LCM 14: 153-4.

Krenkel, W. 1970. Lucilius: Satiren. 2 vols. Leiden. 
Kyle, D. G. 1998. Spectacles of Death in Ancient Rome. London \& New York.

Levin, S. B. 2001. The Ancient Quarrel between Philosophy and Poetry Revisited: Plato and the Greek Literary Tradition. Oxford.

Lowrie, M. 2005. Slander and Horse Law in Horace, Sermones 2.1. Law \& Literature 17: $405-31$.

Manuwald, G. 2009. Concilia deorum: Ein episches Motiv in der römischen Satire. In Per attentam Caesaris aurem. Satire-Die unpolitische Gattung?, ed. F. Felgentreu, F. Mundt and N. Rücker. 46-61. Tübingen.

Manuwald, G. 2011. Roman Republican Theatre. Cambridge.

Martyn, J. R. 1966. Imagery in Lucilius. In Römische Satire. 493-505. Rostock.

Marx, F. 1904. C. Lucilii Carminum Reliquiae. Volumen Prius: Prolegomena, Testimonia, Fasti Luciliani, Carminum Reliquiae, Indices. Leipzig.

Marx, F. 1905. C. Lucilii Carminum Reliquiae. Volumen Posterius: Commentarius. Leipzig.

Mayer, R. 2005. Sleeping with the Enemy: Satire and Philosophy. In The Cambridge Companion to Roman Satire, ed. K. Freudenburg. 146-59. Cambridge.

Mazurek, T. 1997. Self-Parody and the Law in Horace's Satires 1.9. CJ 93: 1-17.

McGinn, T. 2001. Satire and the Law: The Case of Horace. PCPS 47: 81-102.

Michelfeit, J. 1965. Zum Aufbau des ersten Buches des Lucilius. Hermes 93: 113-28.

Morgan, L. 2010. Musa Pedestris: Metre and Meaning in Roman Verse. Oxford.

Murgia, C. E. 1970. Lucilius, Fragment 3 (Marx). TAPA 101: 379-86.

Oliensis, E. 2009. Freud's Rome: Psychoanalysis and Latin Poetry. Cambridge.

Parker, H. N. 1996. Plautus vs. Terence: Audience and Popularity Re-examined. AJP 117: $585-617$.

Parker, H. N. 2000. Flaccus. CQ 50: 455-62. 
Pender, E. E. 2000. Images of Persons Unseen: Plato's Metaphors for the Gods and the Soul. Sankt Augustin.

Petraki, Z. 2011. The Poetics of Philosophical Language: Plato, Poets and Presocratics in the Republic. Berlin \& Boston.

Prinzen, H. 1998. Ennius im Urteil der Antike. Stuttgart.

Puelma Piwonka, M. 1949. Lucilius und Kallimachos. Zur Geschichte einer Gattung der Hellenistisch-Römischen Poesie. Frankfurt.

Robinson, O. F. 2007. Penal Practice and Penal Policy in Ancient Rome. London \& New York.

Romano Martín, S. 2009. El tópico grecolatino del concilio de los dioses. Hildesheim.

Rosen, R. 2007. Making Mockery: The Poetics of Ancient Satire. Oxford.

Ryan, F. X. 1997. Rank and Participation in the Republican Senate. Stuttgart.

Sedley, D. N. 1998. Lucretius and the Transformation of Greek Wisdom. Cambridge.

Shackleton Bailey, D. 1980-1. Stray Lights on Lucilius. CJ 76: 117-18.

Sharrock, A. 2000. Intratextuality: Texts, Parts, and (W)holes in Theory. In Intratextuality:

Greek and Roman Textual Relations, ed. A. Sharrock \& H. Morales. 1-39. Oxford.

Skutsch, O. 1985. The Annals of Q. Ennius. Oxford.

Timpanaro, S. 1994. Nuovi Contributi di Filologia e Storia della Lingua Latina. Bologna.

Turpin, W. 1998. The Epicurean Parasite: Horace, Satires 1.1-3. Ramus 27: 127-40.

Uría, J. 2006. Personal Names and Invective in Cicero. In What's in a Name? The Significance of Proper Names in Classical Latin Literature, ed. J. Booth \& R. Maltby. 1331. Swansea.

Veenstra, J. N. 2002. The Ever-Changing Nature of the Beast: Cultural Change, Lycanthropy and the Question of Substantial Transformation (From Petronius to Del Rio). In The 
Metamorphosis of Magic from Late Antiquity to the Early Modern Period, ed. J. N. Bremmer \& J. R. Veenstra. 133-66. Leuven.

Warmington, E. H. 1938. Remains of Old Latin Vol. 3: Lucilius and the Twelve Tables. Cambridge, MA.

Waszink, J. H. 1970. Zur ersten Satire des Lucilius. In Die römische Satire, ed. D. Korzeniewski. 267-74. Darmstadt.

Waszink, J. H. 1972. Problems concerning the Satura of Ennius. In Ennius: Sept exposés suivis de discussions, ed. O. Skutsch. 99-147. Vandœuvres-Genève.

Watson, L. 1983. The Iambist as Sheep-Dog: Horace, Epode VI 7-8. Mnemosyne 26: 156-9.

Watson, L. 2003. A Commentary on Horace's Epodes. Oxford.

Ziogas, I. 2016. Introduction: Power, Puns, and Politics from Horace to Silius Italicus. In Wordplay and Powerplay in Latin Poetry, ed. P. Mitsis \& I. Ziogas. 1-12. Berlin \& Boston. 